\title{
The presence of two S-layer-protein-encoding genes is conserved among species related to Lactobacillus acidophilus
}

\author{
Hein J. Boot, ${ }^{1}+$ Carin P. A. M. Kolen, ${ }^{1}$ Bruno Pot, ${ }^{2}$ Karel Kersters ${ }^{2}$ and \\ Peter H. Pouwels ${ }^{1,3}$
}

Author for correspondence: Hein J. Boot. Tel: +31320 238881. Fax: + 31320238668. e-mail: H.J.Boot@iD.DLO.NL

1 BioCentrum Amsterdam, University of Amsterdam, Plantage Muidergracht 12, 1018 TV Amsterdam, The Netherlands

2 BCCM/LMG Culture Collection, Laboratory of Microbiology, University of Gent, K. L.

Ledeganckstraat 35, B-9000 Gent, Belgium

3 TNO Nutrition and Food Research Institute, PO Box 5815, 2280 HV Rijswijk, The Netherlands

\begin{abstract}
Previously we have shown that the type strain of Lactobacillus acidophilus possesses two S-protein-encoding genes, one of which is silent, on a chromosomal segment of $\mathbf{6} \mathbf{k b}$. The S-protein-encoding gene in the expression site can be exchanged for the silent S-protein-encoding gene by inversion of this s/p segment. In this study the presence of S-protein and corresponding Sprotein-encoding genes of strains belonging to species that are closely related to $L$. acidophilus was determined. All strains investigated were identified by numerical comparison of highly standardized one-dimensional SDS-PAGE whole-cellular-protein patterns. Western blot and Southern blot methods were used to identify the presence of, and homology between, S-proteins and Sprotein-encoding genes. From these analyses we conclude that strains of $L$. acidophilus, $L$. crispatus, $L$. amylovorus and $L$. gallinarum possess an S-layer and contain two s/p genes. Strains of $L$. helveticus possess an 5 -layer but have only one intact slp gene. Strains of $L$. gasseri, $L$. johnsonii and $L$. delbrueckii subsp. bulgaricus have neither an S-layer nor S-protein-encoding genes hybridizing with probes derived from the $L$. acidophilus s/pA or slpB region. The presence of a highly conserved 5 region in the slp genes of strains of $L$. acidophilus, $L$. crispatus, $L$. amylovorus and $L$. gallinarum suggests that $S$-layer variation is a common feature for strains of these species.
\end{abstract}

\section{Keywords: Lactobacillus, SDS-PAGE identification, surface layer, S-protein, S-layer} variation

\section{INTRODUCTION}

Lactic acid bacteria are widespread in nature and are generally used in the production and preservation of food and feed products like cheese, sauerkraut, meat, yoghurt and silage (McKay \& Baldwin, 1990). Although some Lactobacillus strains can colonize the intestinal tract of the host, living lactobacilli from food or feed preparations are in most cases lost from the gastro-intestinal tract within a few days after the intake has stopped (Lidbeck \& Nord, 1993). Those Lactobacillus strains which are normal inhabitants of the digestive tract must possess the ability to survive in this environment and must be able to adhere to the exposed surface of the epithelial cells. The

† Present address: Institute for Animal Science and Health (ID-DLO), PO Box $65, N L-8200$ AB Lelystad, The Netherlands. adherence of these colonizing lactobacilli is mediated by fimbrial or afimbrial adhesins, which interact with the epithelial cells (Beachey, 1981; Mukai \& Arihara, 1994). The interaction of endogenous lactobacilli with the epithelial surface has attracted the attention of several research groups since Lactobacillus species are reported to possess health-promoting properties when present in the gastro-intestinal and (female) urogenital tract of man and animals. Several effects have been reported to be associated with the presence of lactobacilli, e.g. stimulation of immunoglobulin production (Isolauri et al., 1995; Link-Amster et al., 1994; Perdigón et al., 1993), induction of interferon expression in macrophages (Kitazawa et al., 1992), acidification of the local environment (Zheng et al., 1994), production of $\mathrm{H}_{2} \mathrm{O}_{2}$ (McGroarty, 1993), hypocholesteraemic effects (Fernandes et al., 1987), binding of mutagenic compounds (Orrhage et al., 1994), production of bacteriocins 
(Klaenhammer, 1993) and prevention of adherence of pathogenic bacteria like Salmonella typhimurium and Neisseria gonorrboea to the epithelial cells (Coconnier et al., 1993; Zheng et al., 1994).

The dominant surface protein of many Eu-and Archaeobacteria, including several Lactobacillus species, is the S protein. The $S$ protein is capable of crystallization into a regular structure on the outside of bacteria, the S-layer, which covers the entire cell wall during all stages of growth (for reviews see Beveridge, 1994; Messner \& Sleytr, 1992). The S-layer is present on bacteria of several Lactobacillus species known to inhabit the gastro-intestinal tract (Johnson et al., 1987; Lortal, 1993; Masuda \& Kawata, 1983). Schneitz et al. (1993) reported that the $L$. acidopbilus S-layer acts as an afimbrial adhesin in vitro, and interacts with avian epithelial cells. On the other hand, Greene \& Klaenhammer (1994) reported that the chemical removal of the S-layer of $L$. acidophilus did not influence the in vitro adhesion of bacteria of this strain to Caco-2 cells. Toba et al. (1995) reported that the S-layer of an $L$. crispatus strain was involved in in vitro interaction with human intestinal cells, while the S-layer of the $L$. acidopbilus type strain did not show such an interaction.

Recently we have reported that the $L$, acidophilus type strain possesses two S-protein-encoding genes $(s I p A$ and slpB) (Boot et al., 1995). This L. acidophilus strain is capable of S-layer variation as it can change the position of the $s i p B$ gene from its silent site to the expression site of the $\operatorname{slp} A$ gene by inversion of the slp segment (Boot $t$ t al., 1996). Variation in expression of surface-exposed proteins is known as antigenic variation and is often found for (a)fimbrial adhesins of pathogenic or opportunistic bacteria that are able to adhere to the epithelial cell layer of the gastro-intestinal tract of the host. In this study we have determined whether closely related strains of $L$. acidophilus contain an $\mathrm{S}$ protein and corresponding gene(s) that are similar to those of $L$, acidopbilus. Our results show that L. crispatus, L. amylovorus and L. gallinarum have two slp regions. They all contain two copies of the highly conserved $5^{\prime}$ identity region, which in L. acidopbilus is used for the in vivo chromosomal recombination that leads to S-layer variation. L. belveticus possesses only one sip gene, while L. gasseri, L. jobnsonii and L. delbrweckii subsp. bulgaricus lack S-protein-encoding genes.

\section{METHODS}

Standardized SDSPAGE of whole-cell proteins. For the isolation of whole-cell proteins for identification, all Lactobacillus strains investigated (Table 1 ) and a number of relevant reference strains (Devuyst et al., 1996; Pot et al., 1993) were cultivated aerobically in MRS broth (Difco) at $37^{\circ} \mathrm{C}$ for $24 \mathrm{~h}$. These cultures were used to inoculate two or three Petri dishes of MRS agar (Difco), which were again incubated for $24 \mathrm{~h}$ at $37^{\circ} \mathrm{C}$. The bacteria were scraped from the Petri dishes and about $70 \mathrm{mg}$ of wet cells were washed and then lysed by sonication, SDS treatment and boiling with 2-mercaptoethanol, as described before (Pot et al., 1994). Registration of the protein electrophoretic patterns, normalization of the densitometric traces, pattern storage, grouping of strains by the Pearson product moment correlation coefficient $(r)$ and LPGMA cluster analysis were performed by the techniques described by Pot et al. (1994), using the software package GelCompar version 3.1 (Applied Maths, Kortrijk, Belgium; Vauterin \& Vauterin, 1992).

For numerical analysis of the protein profiles, positions $10-120$ and 171-325 of the 400 points registered were taken into account, omitting the stacking gel/separation gel interface (positions 0 to 9), the zone with disturbing high-density protein bands (S-layer proteins; positions 121-170), and the front of the electrophoretic protein profile (positions 326-400).

Protein isolations. For the isolation of their S-layer proteins, Lactobacillus strains (T'able 1) were cultivated anaerobically in MRS broth at $37^{\circ} \mathrm{C}$ for $16 \mathrm{~h}$. Total protein extracts were made by collecting the bacteria from a $4.0 \mathrm{ml}$ culture by centrifugation $(5000 \mathrm{~g}, 5 \mathrm{~min})$. The cells were washed with $1.0 \mathrm{ml} 20 \mathrm{mM}$ HEPES ( $\mathrm{pH} 7 \cdot 4$ ), resuspended in $50 \mu \mathrm{l} 20 \mathrm{mM}$ HEPES ( $\mathrm{pH} 7 \cdot 4$ ) and $0.3 \mathrm{~g}$ of glass beads $(0.45 \mathrm{~mm}$ diameter) was added. This suspension was vortexed for $1 \mathrm{~min}$ and centrifuged $(5000 \mathrm{~g}$, $1 \mathrm{~min}$ ). The supernatant was used as total-cell extract in the protein analysis. Guanidinium hydrochloride extracts of intact cells were made by collecting bacteria from $10 \mathrm{ml}$ culture by centrifugation $(5000 \mathrm{~g}, 5 \mathrm{~min})$. The bacteria were washed with $1.0 \mathrm{ml} 20 \mathrm{mM}$ HEPES $(\mathrm{pH} 7 \cdot 4)$ and collected by centrifugation (5000 g, $5 \mathrm{~min})$. Part of the cell pellet ( $30 \mathrm{mg}$ net weight) was resuspended in $0.25 \mathrm{ml} 4.0 \mathrm{M}$ guanidine hydrochloride $(\mathrm{pH} 7 \cdot 0)$. This suspension was kept at $37^{\circ} \mathrm{C}$ for $60 \mathrm{~min}$ and centrifuged $(15000 \mathrm{~g}, 5 \mathrm{~min})$. Supernatant was dialysed against water at $4^{\circ} \mathrm{C}$, lyophilized and solubilized in $150 \mu \mathrm{l}$ water.

Western blotting. Total protein extracts were separated on an SDS-PAGE gel (10-15\%) and transferred to nitrocellulose by blotting (Sambrook et al., 1989). Detection of the S-protein antigens was performed as described before (Boot et al., 1993), using the polyclonal antibodies against the $S_{4}$ protein of $L$. acidopbilus $\mathrm{A}$ TCC $4356 \mathrm{~T}$ as the primary antibody and anti-mouse IgG-alkaline phosphatase conjugate (Promega) as the secondary antibody.

Chromosomal DNA isolation. Pre-warmed MRS broth $(225 \mathrm{ml})$ was inoculated with an overnight culture $(25 \mathrm{ml})$ and grown anaerobically for $3.5 \mathrm{~h}$ at $37^{\circ} \mathrm{C}$. Bacteria were harvested by centrifugation $(10 \mathrm{~min}$ at $5000 \mathrm{~g}$ ), washed once with $50 \mathrm{ml}$ $20 \mathrm{mM}$ sodium maleate ( $\mathrm{pH} \mathrm{6.2)}$ ) and resuspended in $40 \mathrm{ml}$ $20 \mathrm{mM}$ sodium maleate ( $\mathrm{pH} \mathrm{6.2)}, 0.6 \mathrm{M}$ lactose, $20 \mathrm{mM}$ magnesium chloride, $80 \mathrm{mg}$ lysozyme $\mathrm{ml}^{-1}$ (Sigma). After incubation for $10 \mathrm{~min}$ at $37^{\circ} \mathrm{C}$ protoplasts were harvested by centrifugation $(10 \mathrm{~min}$ at $3000 \mathrm{~g}$ ) and resuspended in $20 \mathrm{ml}$ $20 \mathrm{mM}$ Tris $/ \mathrm{HCl}(\mathrm{pH} 8.2$ ). After addition of $4.4 \mathrm{ml} 0.5 \mathrm{M}$ EDTA, $5.5 \mathrm{ml} 5 \%$ Sarkosyl was added followed by $3.3 \mathrm{ml} 5 \mathrm{M}$ $\mathrm{NaCl}$. The final suspension was extracted with phenol, phenol/ chloroform/isoamyl alcohol $(25: 24: 1$, by vol. $)$ and chloroform/isoamyl alcohol (24:1, by vol.). Chromosomal DNA was sepatated from the liquid phase after addition of 2 vols of ethanol $\left(20^{\circ} \mathrm{C}\right)$ and stirring with a glass rod. Chromosomal DNA was solubilized in $5 \mathrm{ml} 0.1 \times \mathrm{SSC}(1 \times \mathrm{SSC}$ is $0.15 \mathrm{M} \mathrm{NaCl}$ with $15 \mathrm{mM}$ sodium citrate); $0.4 \mathrm{ml} 10 \mathrm{mg} \mathrm{ml}^{-1}$ R Nase solution was added and the mixture incubated for $20 \mathrm{~min}$ at $37^{\circ} \mathrm{C}$. Then $0.8 \mathrm{ml}$ of a $20 \mathrm{mg} \mathrm{m}^{-1}$ solution of proteinase $\mathrm{K}$ (Boehringer Mannheim) was added and the mixture incubated for $40 \mathrm{~min}$ at $65^{\circ} \mathrm{C}$, followed by addition of $0.7 \mathrm{ml} 5 \mathrm{M} \mathrm{NaCl}$ and repeated phenol/chloroform extractions as described above. Chromosomal DNA was isolated by standard ethanol precipitation (Sambrook et al., 1989), and then dissolved in $0.1 \times$ SSC and stored at $4{ }^{\circ} \mathrm{C}$ for later analysis.

Southern blotting. Chromosomal DNA was digested with either EcoRI or $B c I$ under conditions recommended by the supplier (Pharmacia), separated on a $1 \%(\mathrm{w} / \mathrm{v})$ agarose gel and 
Table 1. Origin of the Lactobacillus strains

\begin{tabular}{|c|c|c|c|}
\hline Strain* & Place of isolation & Obtained from & Reference \\
\hline \multicolumn{4}{|c|}{ L. acidopbilus $(A-1)$} \\
\hline ATCC $4356 \mathrm{~T}$ & Pharynx, human & $\triangle \mathrm{TCC}$ & Boot et al. (1993) \\
\hline LMG 11469 & Intestine, rat & L.MG & Potet al. (1993) \\
\hline \multicolumn{4}{|l|}{ L. crispatus (A-2) } \\
\hline IMG 9479'T & Eye, human & LMG & Devuyst et al. (1996) \\
\hline LMG 12003 & Infant facces & LMG & Devuyst et al. (1996) \\
\hline \multicolumn{4}{|c|}{ L. amylozorus $(\mathrm{A}-3)$} \\
\hline LMG $9496 \mathrm{~T}$ & Cattle waste-con fermentation & LMG & Devuyst et al. (1996) \\
\hline LMG 13135 & Unknown & $\mathrm{LMG}$ & Devuyst et al. (1996) \\
\hline \multicolumn{4}{|c|}{ 1. gallinarum $(A-4)$} \\
\hline LMG $9435 \mathrm{~T}$ & Crop, chicken & $\mathrm{I} . \mathrm{MG}$ & Devuyst et al. (1996) \\
\hline $\mathrm{T}-50$ & Faeces, chicken & T. Fujisawa & Fujisawa et al. (1992) \\
\hline \multicolumn{4}{|l|}{ L. gasseri (B-1) } \\
\hline LMG $9203 \mathrm{~T}$ & Human & LMG & Pot et al. (1993) \\
\hline NCK 89 & Unknown & T. R. Klaenhammer & Muriana \& Klacnhammer (1987) \\
\hline \multicolumn{4}{|l|}{ L. jobnsonii (B-2) } \\
\hline LMG 9436T & Blood, human & LMG & Pot et al. (1993) \\
\hline LMG 11468 & Unknown & LMG & Pot et al. (1993) \\
\hline \multicolumn{4}{|l|}{ L. betveticus } \\
\hline I.MG 6413T & Emmental cheese & LMG & Devuyst et al. (1996) \\
\hline CNRZ 32 & Unknown & E. G. Dudley & Dudley \& Steele (1994) \\
\hline \multicolumn{4}{|c|}{ L. delbrueckit subsp. bulgaricus } \\
\hline LMG $6901 \mathrm{~T}$ & Bulgarian yoghurt & $\mathrm{LMG}$ & Devuyst et al. (1996) \\
\hline LAB514 & Yoghurt & LMG & Devuyst et al. (1996) \\
\hline
\end{tabular}

* DNA homology groups according to Johnson et al. (1980) are given in parentheses; T, type strain. ATCC, American Type Culture Collection, Rockville, MD, USA; LMG, Culture Collection of the Laboratory of Microbiology Gent, University of Gent, Gent, Belgium; CNRZ, Centre National de Recherches Zootechniques, Jouy-en-Josas, France; LAB, Lactic Acid Bacteria Culture Collection of the Laboratory of Microbiology Gent, Department of Physiology, Biochemistry and Microbiology, Faculty of Sciences, University of Gent, Gent, Belgium.

transferred to Hybond filter (Amersham) essentially as described by Southern (1975). The $5^{\prime}$ probe is a restriction fragment of $325 \mathrm{bp}$ derived from the 5 ' part of the slp $A$ gene $[S p h \mathrm{I}(-146)$ to $P_{s t} \mathrm{I}(+179)$; numbers are relative to the $\operatorname{sip} A$ start codon]. The $3^{\prime}$ probe is a PCR fragment of 369 bp derived from the $3^{\prime}$ end of the sip. $A$ gene (nt 1017-1386 relative to the $s / p A$ start codon). The sip. 4 probe is a $173 \mathrm{bp}$ restriction fragment of the sipA ORF $\mid P s t I(+179)$ to $P s t \mathrm{I}(+352)$; numbers are relative to the $s i p . A$ start codon), The slp $B$ probe is a 149 bp PCR-amplified part of the sipB ORF (nt $175-324$ relative to the s/p $B$ start codon), which is $57 \%$ identical with the corresponding region of sip $A$ ORF.

All probes were separated by agarose gel electrophoresis, purified from the agar with Glassmilk (Geneclean II; Bio 101), and labelled with $\left[\alpha^{32} \mathrm{P}\right] \mathrm{d}$ ATP using random-primer labeiling (Prime-a-Gene; Promega). Hybridization $(6 \times \mathrm{SSC} / 0 \cdot 1 \% \mathrm{SDS}$ ) and washing (three times in $0.1 \times \mathrm{SSC} / 0.1 \% \mathrm{SDS}$ ) were performed at temperatures indicated in the legends of Figs 5 to 7 .

\section{RESULTS}

\section{Identification of strains}

The type strain and various other strains of $L$. acidopbilus (A-1), L. crispatus (A-2), L. amylovorus $(\Lambda-3), L$. gallinarum (A-4), I. gasseri, (B-1), L. jobnsonii (B-2), L. belveticus and
L. delbrueckii subsp. bulgaricus (Table 1) were analysed in a standardized SDS-PAGE analysis of total cellular proteins. The protein profiles of these strains were compared to a database of normalized protein fingerprints derived from reference strains from almost all known species of lactic acid bacteria. Only relevant reference strains were included to produce the dendrogram presented in Fig. 1. Our SDS-PAGE analysis clearly discriminated between the six different species, which were formerly referred to as L. acidophilus (Johnson et al., 1980), as defined by Fujisawa et al. (1992). For the type strain of $L$. acidopbilus, three different subcultures, independently obtained from different culture collections, were separately processed and compared. Under the above-mentioned conditions, a correlation of $r \geqslant 0.88$ was calculated between these strains. 'The two colony variants of the type strains, LMG $9496 \mathrm{~T}$ and LMG $6901 \mathrm{~T}$, of $L$. amylovorus and of $L_{\text {. }}$. delbrueckii subsp. bulgaricus (labelled $\mathrm{t} 1$ and $\mathrm{t} 2$ ) were clearly very similar $(r \geqslant$ 0.95 ; Fig. 1). The first cluster comprised all L. acidopbilus strains investigated, including the type strain and is equivalent to DNA homology group $A-1$ (Johnson et al., 1980). Cluster I was delineated at a correlation level of $r$ $\geqslant 0.81$ and showed a correlation of $r \geqslant 0.77$ with its closest neighbour, L. crispatus, forming cluster II. This 


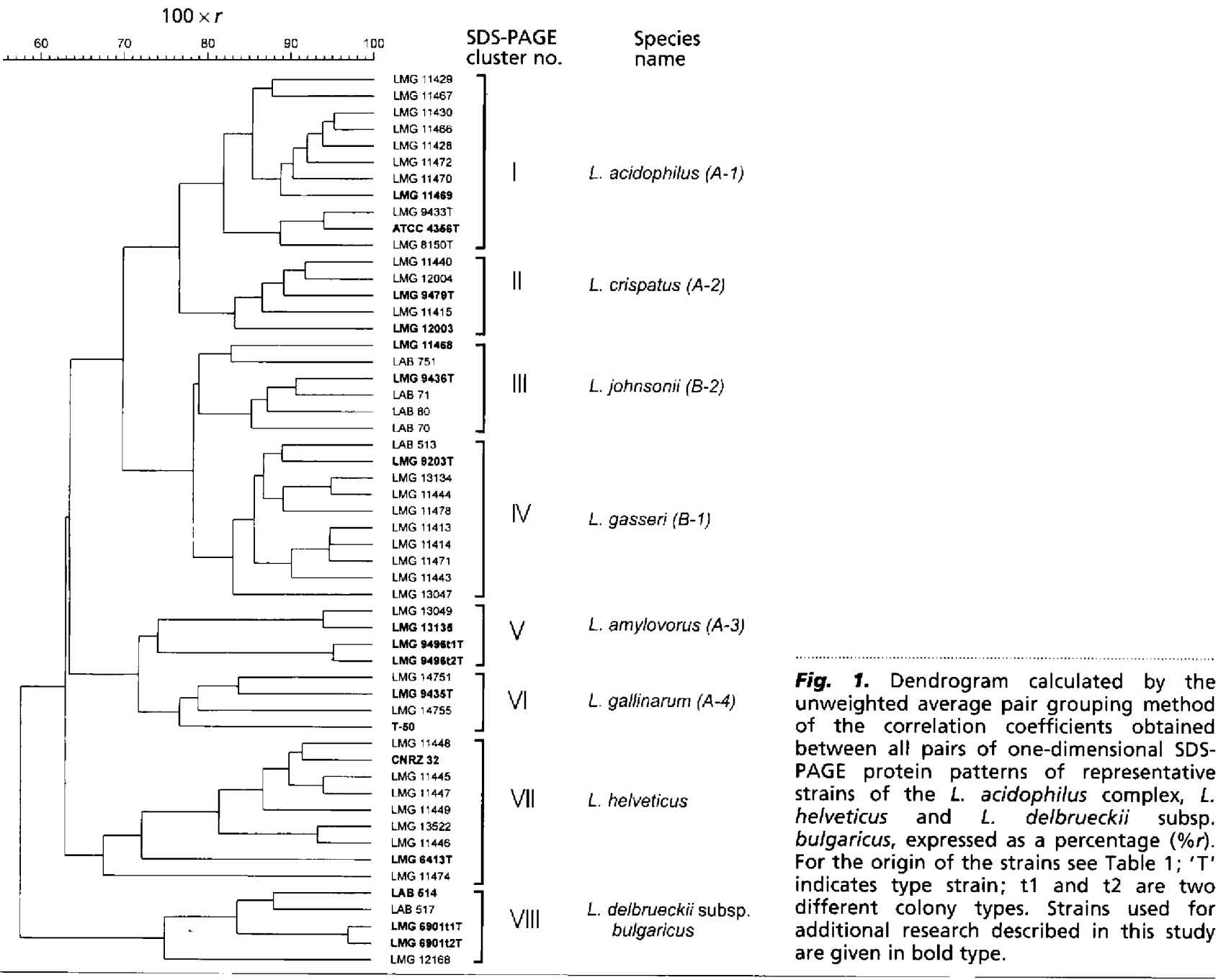

second cluster, equivalent to DNA similarity group A-2 (Johnson et al., 1980), was delineated above $r=0.82$ and contained both strains investigated for S-layer proteins. Cluster III, analogous to DNA homology group B-2, contained all $L$. jobnsonii strains investigated and was delineated above $r=0.79$. L. gasseri strains (DNA homology group B-1), including the type strain, formed cluster IV at a correlation level of $r=0.83$. It should be noted that, for example, DNA homology groups A-1 and A-2 showed higher correlation with the DNA homology groups B-1 and B-2 $(r=0.79)$ than with the DNA homology group A-3, which is represented by the $L$. amylovorus strains (cluster $\mathrm{V}$ in Fig. $1 ; r=0.73$ ). This indicates that, aithough SDS-PAGE of whole-cell proteins is very useful in grouping bacteria at the species level, no phylogenetic conclusions should be drawn from the dendrograms calculated from similarity values. Cluster VI groups all L. gallinarum strains (DNA homology group A-4) at a correlation of $r=0 \cdot 76 . L$. belveticus, which is also related to the above-mentioned species of the $L$. acidophilus group, forms cluster VII, and, although well separated from the other species, shows considerable heterogeneity with a correlation level of $r=0.68$. The four strains selected from $L$. delbrueckii subsp. bulgaricus form cluster VIII at $r=0.75$.

\section{S-layer protein analysis}

The presence of an S-layer on the outside of bacteria belonging to the different Lactobacillus species can be deduced from the presence of a dominant protein band with a molecular mass of about $45 \mathrm{kDa}$ in the (surface) protein profile of these bacteria (Boot et al., 1993; Johnson et al., 1987). Guanidinium hydrochloride extracts of surface proteins of intact cells of the type strains of the different Lactobacillus species were analysed in a separate SDS-PAGE gel. A dominant protein band of about $45 \mathrm{kDa}$ was present in the extracts of the type strains of $L$. acidophilus, L. crispatus, L. amylovorus, L. gallinarum and $L$. belveticus, showing the presence of S-layer proteins. On the other hand, the type strains of L. gasseri, L. jobnsonii and L. delbrueckii subsp. bulgaricus did not have such a protein band at the $45 \mathrm{kDa}$ position, indicating the absence of an S-layer (Fig. 2). For each species the guanidinium hydrochloride extract of an additional strain was investigated by SDS-PAGE analysis beside the respective 


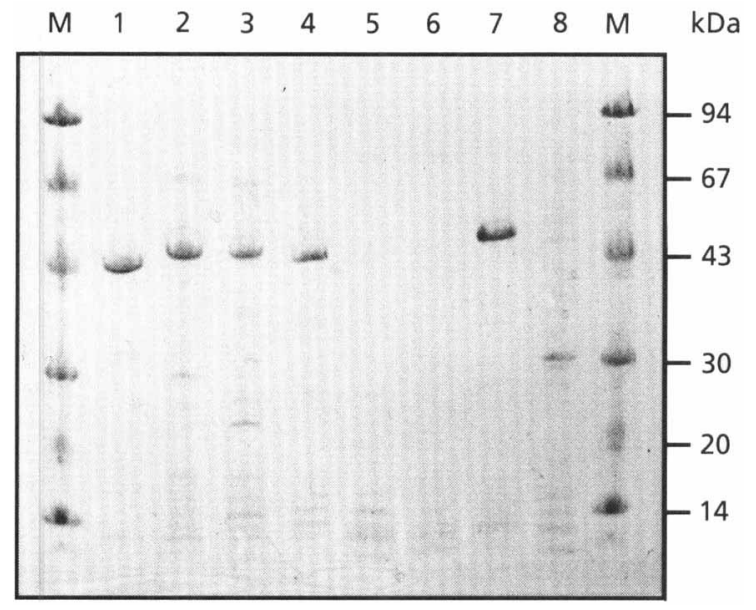

Fig. 2. Surface proteins of intact cells of Lactobacillus strains. The surface proteins of the type strains of $L$. acidophilus (lane 1), L. crispatus (lane 2), L. amylovorus (lane 3 ), L. gallinarum (lane 4), L. gasseri (lane 5), L. johnsonii (lane 6), L. helveticus (lane 7) and L. delbrueckii subsp. bulgaricus (lane 8 ) were extracted with guanidinium hydrochloride and analysed on an SDS-PAGE gel (10-15\%). The gel was stained with Coomassie blue after electrophoresis. The molecular masses of the marker proteins (lane $M$ ) are given on the right-hand side. type strain (data not shown). The presence or absence of an S-layer was species dependent for all the investigated Lactobacillus strains.

\section{Western blot analysis}

To determine the relationship of the $S_{A}$-protein of the $L$. acidophilus type strain with the $S$-proteins of the other strains, we used polyclonal murine antibodics directed against the $S_{A}$-protein of the $L$. acidopbilus type strain in a Western blot of the total protein extracts from the Lactobacillus strains (Fig. 3). From this analysis it appeared that the $S$ protein of the $L$. crispatus strains is not recognized by the antibodies used, while the S-proteins of I. amylovorus, L. gallinarum and $L$. belveticus show a lower affinity compared with the $S$ proteins of the L. acidophilus strains. As expected, no proteins of the $L$. gasseri, $L$. jobnsonii and $L$. delbrueckii subsp. bulgaricus extracts reacted with the antibodies used.

\section{Southern blot analysis}

The L. acidophilus type strain shows S-layer variation between two $\mathrm{S}$-proteins ( $\mathrm{S}_{\mathrm{A}}$ - and $\mathrm{S}_{\mathrm{B}}$-protein) which have $50 \%$ sequence identity in the $\mathrm{N}$-terminal and middle part

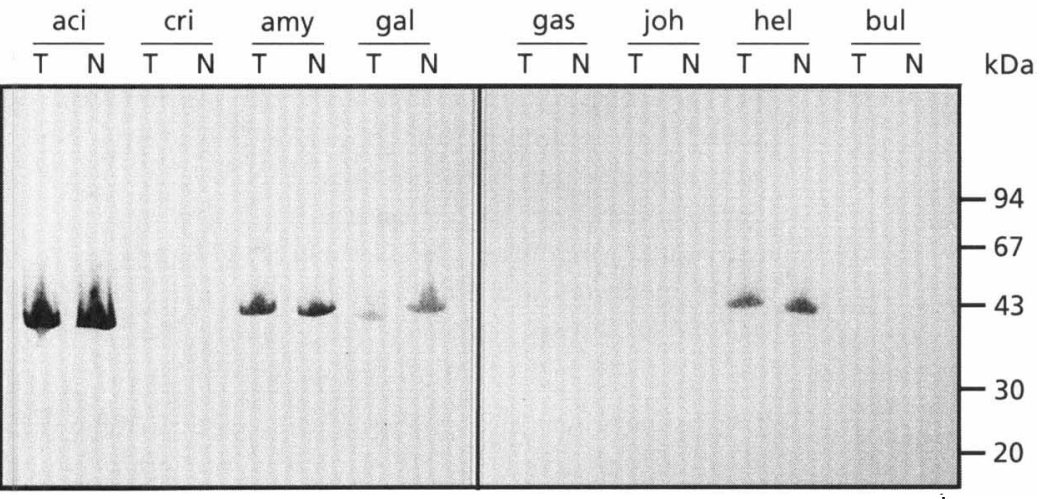

Fig. 3. Western blot analysis of total protein extracts of the type strains (T) and non-type strains $(\mathrm{N})$ of Lactobacillus species. Abbreviations above the lanes: aci, $L$ acidophilus; cri, $L$. crispatus; amy, $L$. amylovorus; gal, $L$. gallinarum; gas, $L$. gasseri; joh, $L$. johnsonii; hel, $L$. helveticus; bul, $L$. delbrueckii subsp. bulgaricus. 5 protein antigens were detected by polyclonal antibodies against the $S_{A}$-protein of $L$. acidophilus type strain (Boot et al., 1993). Molecular mass markers are indicated on the right-hand side.

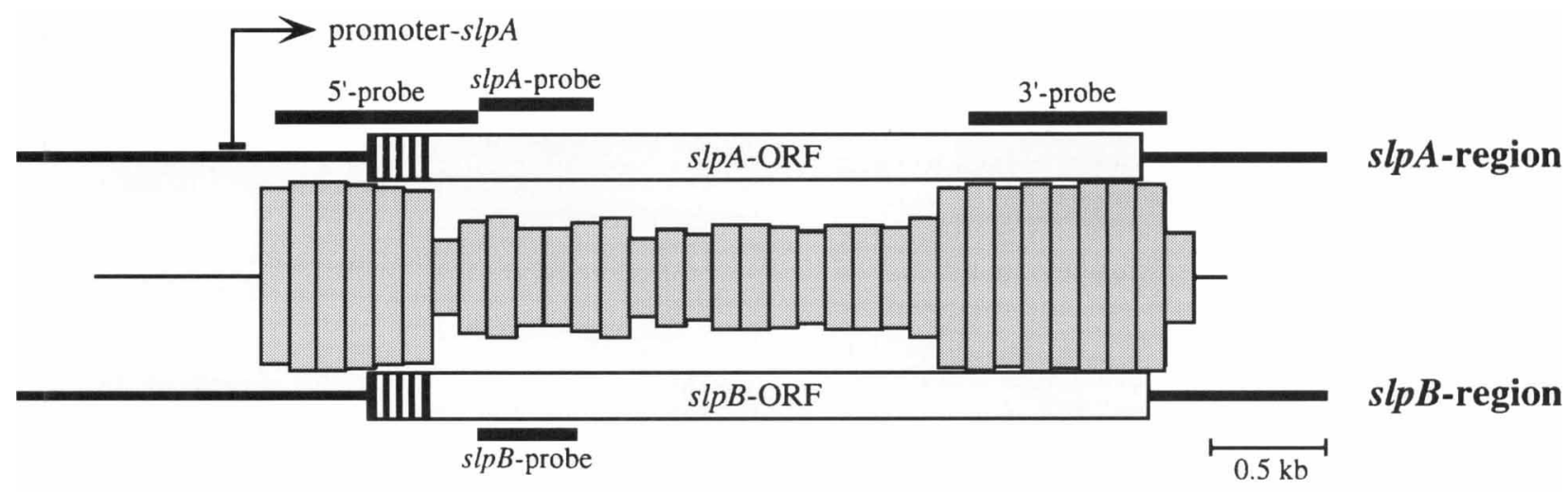

Fig. 4. Schematic drawing of the chromosomal slpA and $s / p B$ regions of the $L$. acidophilus type strain. The percentage identity between 50 nucleotides of the s/p regions is represented by shaded boxes between the two sequences. A full-size box means completely identical, while a line means no detectable identity. The probes used in the Southern blot analysis are indicated by black bars above the $\operatorname{sip} A$ region or below the $s / p B$ region. The regions which encode the secretion leader sequences are indicated by vertical lines in the ORFs of both slp regions. 
(a)

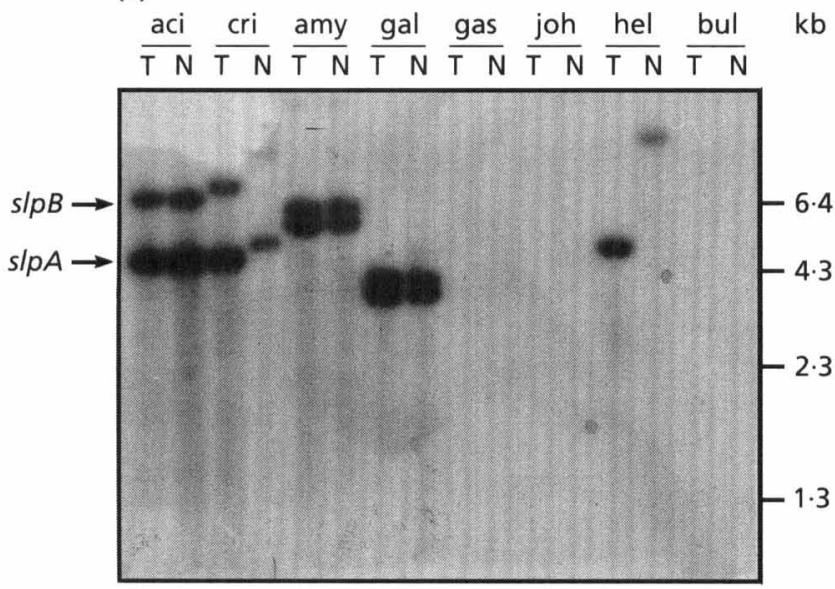

(b)

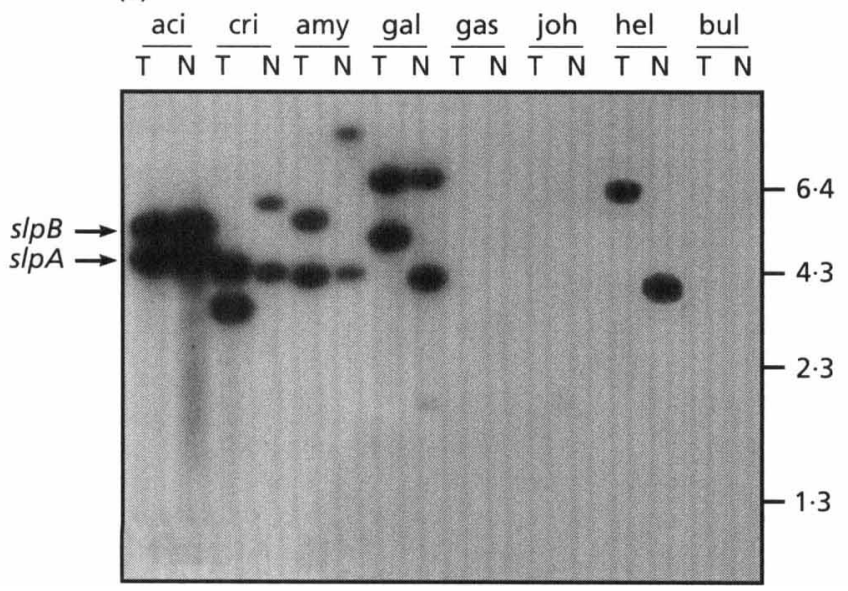

Fig. 5. Autoradiograph of Southern blot analysis of (a) EcoRland (b) Bc/l-digested chromosomal DNA of Lactobacillus strains (see legend to Fig. 3). Hybridization with the $5^{\prime}$ probe was performed at $50^{\circ} \mathrm{C}$ and washing $(0.1 \times 5 S \mathrm{C} / 0.1 \%$ SDS) was performed at $65^{\circ} \mathrm{C}$. The $\operatorname{sipA}$ and $s / p B$ regions in the lane of the type strain of $L$. acidophilus are indicated on the left-hand side. DNA length markers (fragments of BstEll-digested wild-type $\lambda$ phage) are indicated on the right-hand side.

of the mature proteins and have identical sequences at the C terminus (Boot et al., 1995). The two genes encoding these proteins share two regions of identical sequence: a region of 280 bp between the slp promoter and the start of the mature proteins and a region of 430 bp encoding the C-terminal part of the S-proteins. Chromosomal DNA of the Lactobacillus strains was extracted and analysed by Southern blot analysis using probes derived from the $\operatorname{sip} A$ and $s / p B$ regions of the L. acidopbilus type strain (Fig. 4). In the first Southern blot analysis (Fig. 5) we used a probe surrounding the translation start point of the $\operatorname{sip} A$ gene of the $L$. acidophilus type strain. This probe was derived from the $s / p A$ region and $75 \%$ of its length is identical to the corresponding $s / p B$ region. Two bands hybridized with the chromosomal DNAs of the $L$. acidophilus, L. crispatus, L. amylovorus and L. gallinarum strains, digested with either EcoRI (Fig. 5a) or BclI (Fig.

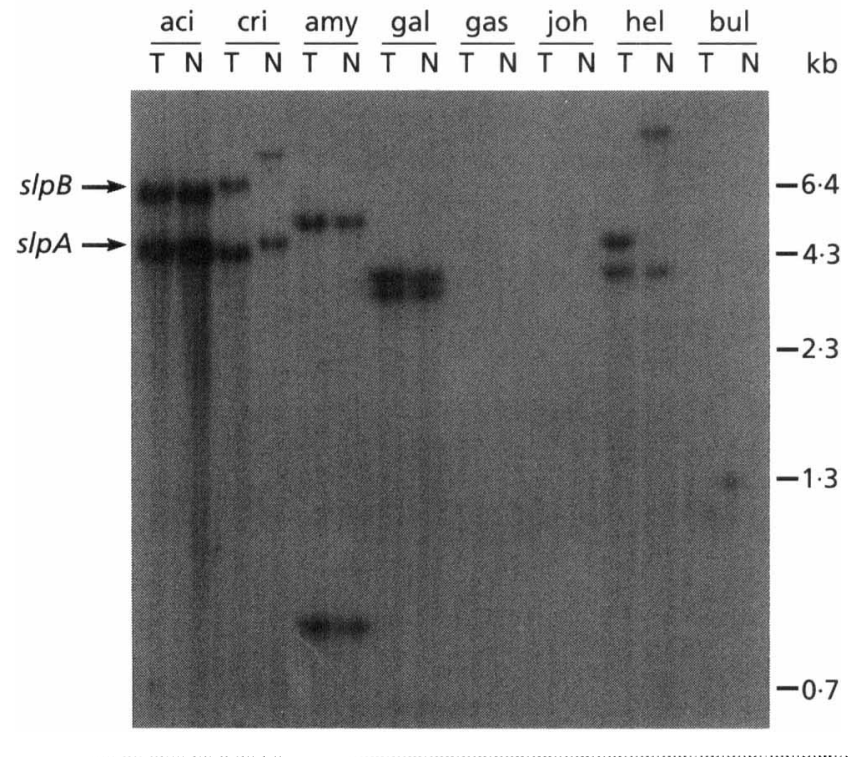

Fig. 6. Autoradiogram of Southern blot analysis of EcoRIdigested chromosomal DNA of the Lactobacillus strains (see legend to Fig. 3 for lane descriptions). Hybridization with the 3 probe was performed at $50^{\circ} \mathrm{C}$ and washing $(0.1 \times 5 S C 10.1 \%$ SDS) was performed at $65^{\circ} \mathrm{C}$. See legend to Fig. 5 for DNA length markers and arrow descriptions.

$5 b)$. These two bands are most likely due to the presence of two chromosomal sip loci, as shown for the $L$. acidophilus strains (Boot et al., 1995). Only one band hybridized when chromosomal DNA of L. belveticus was used, indicating that the strains of this species contain only one slp region. No hybridizing bands were found with chromosomal DNA of $L$. gasseri, L. jobnsonii or $L$. delbrieckii subsp. bulgaricus, suggesting that these strains do not have S-protein-encoding genes.

In the Southern blot of Fig. 6 we used a probe which was also derived from the $\operatorname{sip} A$ region, but encoding the $C$ terminal part of the $S_{A}$-protein. This probe was $92 \%$ identical with the corresponding part of the slpB region. The hybridization pattern of this Southern blot was identical with that of Fig. 5(a) for most of the strains, indicating that the two hybridizing bands in these Southern blots were not due to restriction sites within one single slp region, but were due to the presence of two separated slp regions. One remarkable difference between the hybridization patterns of Fig. 5(a) and Fig. 6 is that two signals were obtained for both $L$. belveticus strains with the $3^{\prime}$ probe (Fig. 6), compared to only one signal with the $5^{\prime}$ probe (Fig. 5a).

Further characterization of the slp regions of the different strains was obtained by Southern blot analysis using probes that are specific for the $\operatorname{sip} A$ or $s / p B$ gene of the $L$. acidophilus type strain. No heterologous signals were obtained with the same, stringent, washing conditions used for the $5^{\prime}$ and $3^{\prime}$ probes $(0 \cdot 1 \times \mathrm{SSC} / 0 \cdot 1 \% \mathrm{SDS}$ at $65^{\circ} \mathrm{C}$; data not shown). We therefore repeated the experiment using moderate washing conditions $(0.1 \times$ $\mathrm{SSC} / 0 \cdot 1 \% \mathrm{SDS}$ at $50{ }^{\circ} \mathrm{C}$ ) (Fig. 7 ). Under these conditions, 
(a)

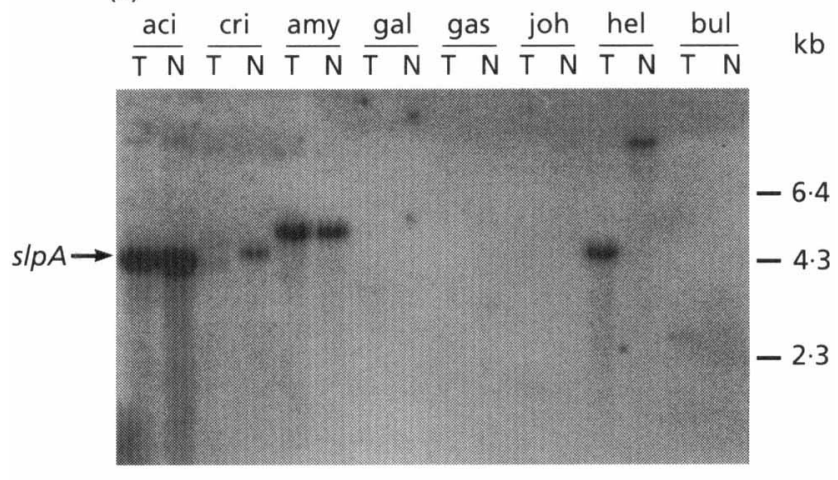

(b)

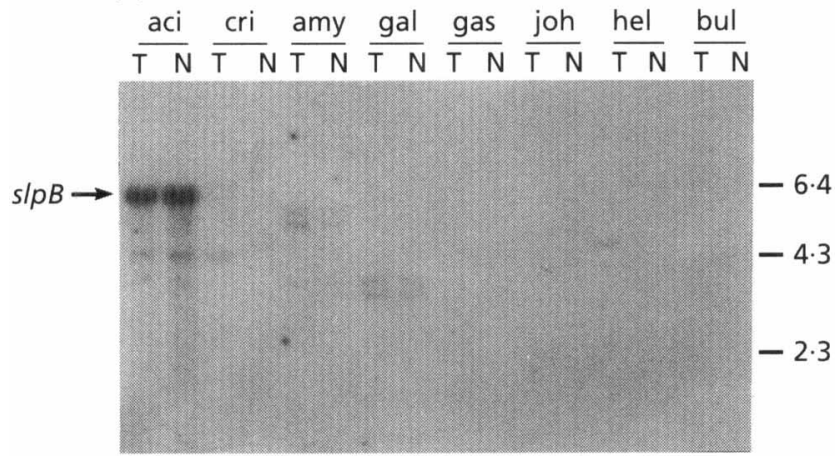

Fig. 7. Autoradiogram of Southern blot analysis of EcoRIdigested chromosomal DNA of the Lactobacillus strains (see legend to Fig. 3 for lane descriptions). The sipA probe (a) or the s/pB probe (b) was used to visualize the s/p regions. Hybridization and washing $(0.1 \times$ SSC/0.1\% SDS) were both performed at $50^{\circ} \mathrm{C}$. See legend to Fig. 5 for DNA length markers and arrow descriptions.

DNA of both strains of L. amylovorus and L. belveticus as well as the non-type strain of L. crispatus contained one dominant hybridizing $s / p$ region when the $\operatorname{sip} A$ probe (Fig. 7a) was used. Both sip regions of the two $L$. amylovorus and $L$, gallinarum strains and one slp region of the type strains of $L$. crispatus and L. belveticus yielded faint signals when the $\operatorname{sip} B$ probe (Fig. $7 \mathrm{~b}$ ) was used. These faint signals are not very specific as the $s / p . A$ region of the L. acidopbilus type strain yields a signal of about the same intensity, while the identity of this region with the probe used is only $57 \%$. The DNA of the type strain of $L$. crispatus yielded two hybridizing bands when the $\operatorname{sip} A$ probe was used (Fig. 7a). The lower molecular mass signal $(4.2 \mathrm{~kb})$ represents the $s / p$ region which also hybridizes with the $5^{\prime}$ probe (Fig. 5a) and $3^{\prime}$ probe (Fig. 6). The nature of the other signal $(4 \cdot 8 \mathrm{~kb})$ is presently unclear. The results obtained with the $s / p A$ - and $s / p B$-specific probes show that the $s / p B$-specific sequence is less conserved among the investigated Lactobacillus strains than the $\operatorname{sip} A$-specific sequence.

\section{DISCUSSION}

Recently we found that the type strain of L. acidophilus, which has an S-layer, is capable of S-layer variation (Boot et al., 1996). The present study was initiated to determine whether related species of $L$. acidophilus possess related $S$ proteins and whether these species are also capable of $\mathrm{S}$ layer variation. First we identified the strains using a standardized SDS-PAGE identification method, previously shown to yield groupings similar to those revealed by DNA:DNA hybridization and $16 \mathrm{~S}$ rRNA probe hybridization (Pot et al., 1993) (Fig. 1). The presence of an S-layer on the outside of the type strain of each species was subsequently determined by extracting the surface proteins of intact cells with $4 \mathrm{M}$ guanidinium hydrochloride and analysing those protein extracts by SDSPAGE. From our analyses it is clear that the type strain and at least one other strain of the species $L$. acidophilus, $L$. crispatus, L. amylovorus, L. gallinarum and L. beiveticus possess an S-layer. On the other hand, the type strain and at least one other strain of the species L. gasseri, L. johnsonii and $L$. delbrueckii subsp. bulgaricus do not possess such an S-layer.

To date, S-layer variation has been described for three different bacterial species: Campylobacter fetus (Tummuru \& Blaser, 1993), Bacillus stearotbermopbilus (Sára \& Sleytr, 1994) and L. acidopbilus (Boot et al., 1996). For B. stearothermophilus, it has been shown that certain growth conditions are inductive or selective for a specific $S$ protein. Nothing is known, however, about the selectivity of growth conditions for the expression of the S-proteins of $L$. acidophilus. The growth conditions used in the present and previous studies seem to be favourable for $S_{A}$. protein expression, as expression of the $S_{B}$-protein was never detected (Boot et al., 1996). Since the growth conditions favouring the expression of the variant $\mathrm{S}$ proteins are not known, we used an indirect approach to determine whether S-layer variation is possible for Lactobacillus strains belonging to different species. Western blot analysis using polyclonal antibodies against the $\mathrm{S}_{\mathrm{A}}$-protein of the L. acidopbilus type strain shows that the S-proteins of L. amylovorus, L. gallinarum and $L_{\text {. }}$. belveticus have antigenic determinants in common with the $S_{\Lambda}$ protein. L. crispatus on the other hand does not have those common determinants (Fig. 3). Based upon the results of this Western blot analysis, we expected that the genes encoding the S-proteins of different strains would show some sequence identity. This enabled us to determine the number of $s / p$ loci for the different strains by using probes derived from the two L. acidoplilus sip regions in Southern blot analysis. Only strains that have muitiple sip regions might be capable of S-layer variation using the same mechanism of chromosomal recombination as we have found for the $L_{\text {. }}$ acidophilus type strain (Boot et al., 1996).

The results of the Southern blot analysis using chromosomal DNA of the type strain and another strain of $L$. acidophilus, L. crispatus, L. amylovorus, L. gallinarum and $L$. belveticus are summarized in Table 2 . The two strains of $I$.. acidophilus, L. crispatus, L. amylovorus and L. gallinarum possess two regions which hybridize with both the $5^{\prime}$ and the $3^{\prime}$ probe (Figs 5 and 6). Apart from these general probes, we also used probes that are specific for the two sip genes of L. acidopbilui (Fig. 4). This analysis shows that there are several strains, including the L. belveticus strains, 
Table 2. Properties of S proteins and S-protein-encoding genes of Lactobacillus strains

\begin{tabular}{|c|c|c|c|c|c|}
\hline \multirow[t]{2}{*}{ Strain* } & \multirow[t]{2}{*}{ Western blot ${ }^{+}$} & \multicolumn{4}{|c|}{ Hybridization signals $\ddagger$} \\
\hline & & $5^{\prime}$ probe & $3^{\prime}$ probe & $\operatorname{sip} A$ probe & slpB probe \\
\hline \multicolumn{6}{|l|}{ L. acidophilus } \\
\hline ATCC $4356 \mathrm{~T}$ & +++ & 2 & 2 & 1 & 1 \\
\hline LMG 11469 & +++ & 2 & 2 & 1 & 1 \\
\hline \multicolumn{6}{|l|}{ L. crispatus } \\
\hline LMG 9479T & - & 2 & 2 & - & - \\
\hline LMG 12003 & - & 2 & 2 & 1 & - \\
\hline \multicolumn{6}{|l|}{ I. amyloworus } \\
\hline LMG $9496 \mathrm{~T}$ & ++ & 2 & 2 & 1 & - \\
\hline LMG 13135 & $+t$ & 2 & 2 & 1 & - \\
\hline \multicolumn{6}{|l|}{ L. gallinarum } \\
\hline LMG $9435 \mathrm{~T}$ & + & 2 & 2 & - & - \\
\hline $\mathrm{T}-50$ & + & 2 & 2 & - & - \\
\hline \multicolumn{6}{|l|}{ L. belueticus } \\
\hline LMG $6413 \mathrm{~T}$ & + & 1 & 2 & 1 & - \\
\hline CNRZ 32 & ++ & 1 & 2 & 1 & - \\
\hline
\end{tabular}

* Strains belonging to the species L. gasseri, L. jobnsonii and L. delbrueckii subsp. bulgaricus have neither an S-layer nor S-protein-encoding regions and are omitted from this table.

$\dagger$ The signal intensity as shown in Fig. 4 is represented by: +++ , strong; ++ , moderate; + , weak; and - , no reaction.

$\ddagger$ Number of independent hybridization signals in a Southern blot analysis, as deduced from the results of Figs 6 to 8 ; - , no signal.

with a chromosomal region with moderate identity with the slp $A$ probe (Fig. $7 a)$. No strains contain regions which hybridize with the $s / p B$ probe when using the same hybridization and washing conditions as used for the $\operatorname{sip} A$ probe (Fig. 7b). The gene encoding the $\mathrm{S}_{\mathrm{A}}$-protein is apparently more conserved than the gene encoding the second $\mathrm{S}$ protein of each strain studied.

The L. belveticus strains show only one band that hybridizes with the $5^{\prime}$ probe and the $s / p A$ probe. However, with the $3^{\prime}$ probe, two bands hybridize with $L$. belveticus DNA digested with EcoRI (Fig. 6) and with Bcll (data not shown). One explanation for this difference in hybridization pattern might be that restriction sites are present in the region between the probes. The nucleotide sequences of the S-protein-encoding genes of the $L$. belveticus strains CNRZ 1269 and CNRZ 892 have been elucidated (EMBL accession no.s X92752 and X91199, respectively). These sequences differ by only one nucleotide and no restriction sites are present for either EcoRI or $B c / I$ in these slp genes or in the first 150 nt downstream of the slp gene of these strains. Although we cannot exclude that the sequence of the slp genes of $L$. belveticus strains we have used is different from those of the published $L$. belveticus slp genes, it seems unlikely that the recognition sites for two randomly chosen restriction enzymes have changed. A more plausible explanation is that the $L$. belveticus strains which we analysed still have (part of) the 3 identity region of a second slp region, while they have lost the 5' identity region. A silent $\mathrm{S}$-protein-encoding gene which lacked the $5^{\prime}$ part of the coding region has already been described for Bacillus sphaericus (Bowditch et al., 1989). S-layer variation using the same mechanism as observed with $I$. acidopbilus is thus not possible for the $L$. belveticus strains since they lack the 5 ' region of identity used for inversion of the slp segment by $L$. acidophilus ATCC 4356T.

The presence of an S-layer in our study is speciesdependent for all the Lactobacillus strains tested, including L. delbrueckii subsp. bulgaricus. To determine whether we could confirm the result of Masuda \& Kawata (1983), that at least some $L_{\text {. }}$ delbrueckii subsp. bulgaricus strains (e.g. YIT0045) possess an S-layer, we have analysed 10 different strains of $L$. delbrueckii subsp. bulgaricus by SDS-PAGE and Western blotting. Most of the L. delbrueckii subsp. bulgaricus strains were obtained from the Unilever culture collection, but the strains used by Lortal (1993) [CNRZ 208 (type strain), 369 and 416] and strain YIT0045 were also analysed. None of these L. delbrueckit subsp. bulgaricus strains, including strain YIT0045 obtained from the Yakult culture collection, contained an S-layer or $\mathrm{S}$ protein (data not shown). The strain of $L$. delbrueckit subsp. bulgaricus described by Masuda \& Kawata (referred to here as M-YIT0045) and provided by K. Masuda contained an S-layer (data not shown). However, this strain appeared not to be a $L$. delbrueckii subsp. bulgaricus but a $L$. belveticus strain in our numerical comparison of the SDS-PAGE protein patterns of whole-cell protcins. Several reports, including this one, show that bacteria belonging to the $L$. belveticus species indeed possess an $S$ layer. Furthermore, Masuda \& Kawata (1983) also 
reported that L. fermentum NCTC 7230 (LMG 8897) possesses an S-layer. In our analysis L. fermentum LMG 8897 and two other L. fermentum strains (L.MG 8896 and 104R; Blomberg et al., 1993) lacked an S-layer (data not shown). In our taxonomic SDS-PAGE analysis, however, the L. fermentum strain described by Masuda \& Kawata (1983), appeared not to belong to a known species of the genus Lactobacillus and definitely is not a L. fermentum strain (data not shown). Further taxonomic analysis is needed to reveal the identity of this strain. Strains of $L$. delbrueckii subsp. bulgaricus and L. fermentum should in our opinion be referred to as non-S-layer possessing strains.

The signal intensity of the slp regions of 1 .. crispatus, $I$. amylovorus, L. gallinarmm and L. beheticus is less with the 3' probe than with the 5 ' probe (compare Fig. $5 b$ with Fig. 6). This indicates that the nucleotide sequence in the region of the translation start ( $5^{\prime}$ identity region) is more conserved among the S-protein-encoding regions of lactobacilli, while the region of the $3^{\prime}$ probe is less conserved. The highly conscrved $5^{\prime}$ identity region does not code for a part of the mature protein, in contrast to the 3' identity region (Boot et al, 1995). A reason for conservation of the 5 ' region might be that a sequencespecific trans-acting factor binds to this conserved region to facilitatc a high frequency of site-specific chromosomal recombination. Some properties of the different $S$-proteins are probably conserved, i.e. interaction with the underlying cell wall and crystallization into a reguiar structure. Other properties, like exposed antigens or interaction with foreign receptors, are presumably different for different S-proteins. The sequence identity near the C terminus and the sequence variation near the $N^{\top}$ terminus might reflect these opposing constraints.

In this study we have shown that some regions of Sprotein-encoding genes of $L$. acidophilus, L. crispatus, $L$. amylovorus and $L$.gallinarum have a high degree of sequence identity, while other regions sharc only a very limited sequence identity. On the basis of the results obtained it scems possible to design a strategy which can rapidly prove or disprove whether a strain belongs to one of these Lactobacillus species either by S-protein epitope-specific antibodies or by an S-protein DNA sequence-specific (PCR) method.

\section{ACKNOWLEDGEMENTS}

We thank Katrien Vandemeulebroecke for excellent technical assistance and Patricia Conway, Sylvie Lortal, Ed Dudley, Tomohiko Fujisawa, Todd Klaenhammer, Kuniyoshi Masuda and the Unilever and Yakult companies for providing some of the Lactobacillus strains used in this study. Part of this study was financially supported by the Foundation for $\Gamma$ echnical Sciences (STW) of the Netherlands. B. Pot, K. Kersters and P. H. Pouwels are indebted to the Biotechnology (BIOTECH) Gproject on Lactic Acid Bacteria of the Commission of the European Communities, contract BIOT-CT94-3055

\section{NOTE ADDED IN PROOF}

Lactobacillus strain NCK89 is most likely not a $L$. gasseri but a L. jobnsonii (T. R. Klacnhammer, North Carolina State University, LSA, personal communication).

\section{REFERENCES}

Beachey, E. H. (1981). Bacterial adherence: adhesin-receptor interactions mediating the attachment of bacteria to mucosal surfaces. I Infel Dis 143, 325345.

Beveridge, T. J. (1994). Bacterial S-layers. Curr Opin Strut Biol 4, 204-212.

Blomberg, L., Henriksson, A. \& Conway. P. L. (1993). Inhibition of

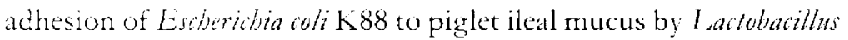
spp. Appl Fniran Microbiol 59, 34-39.

Boot, H. J., Kolen, C. P. A. M., van Noort, J. M. \& Pouwels, P. H. (1993). S-layer protein of Lactobacillas acidophilus ATCC 4356: purification, expression in Escherichia coli, and nucleotide sequence of the corresponding gene. J Bateriol 175, 6089-6096.

Boot, H. J., Kolen, C. P. A. M. \& Pouwels, P. H. (1995). Identification, cloning and nucleotide sequence of a silent $\mathrm{S}$-layer protein gene of Lactobacillas acidophilus ATCC 4356 which has extensive similarity with the S-layer protein gene of this species. $J$ Bacteriol 177, 7222-7230.

Boot, H. J., Kolen, C. P. A. M. \& Pouwels, P. H. (1996). Interchange of the active and silent $\mathrm{S}$-layer procein genes of Lactobacillas acidsphilus by inversion of the chromosomal slp segment. Mol Whobiol (in press).

Bowditch, R. D., Baumann, P. \& Yousten, A. A. (1989). Cloning and sequencing of the gene encoding a 125 -kilodalton surface-layer protein from Bacillus spbaericus 2362 and of a related cryptic gene. $J$ Bateriol 171, 4178-4188.

Coconnier, M.-H., Bernet, M.-F., Kernéis, S., Chauvière, G., Fourniat, J. \& Servin, A. L. (1993). Inhibition of adhesion of enteroinvasive pathogens to human intestinal Caco-2 cells by I actobacilhs acidophilus strain I.B decreases bacterial invasion. FEMS Mirrobiol Lett 110, 299-306.

Devuyst, L., Callewaert, R. \& Pot, B. (1996). Characterization of the antagonistic activity of $T$ atobatilis any loworus DCE 417 and large scale isolation of its bacteriocin amylovorin L471. Syst Appl Hirbbiol VOL, (in press).

Dudley, E. G. \& Steele, J. L. (1994). Nucleotide sequence and distribution of the pep PN gene from I atoballus beluetion CNR732. Flivis Nicrobiol Lett $119,41-46$.

Fernandes, C. F., Shahani, K. M. \& Amer, M. A. (1987). Therapeutic role of dietary lactobacilli and lactobacillic fermented dairy products. FEMS Hicrobiol Ren 46, 343-356.

Fujisawa, T., Benno, Y., Yaeshima, T. \& Mitsuoka, T. (1992). Taxonomic study of the Lactobacillas acidophilus group, with recognition of Laciabailins galliwaram sp. nov, and Latobaillus johnomil sp. nov and synonymy of Lactobacilits acidophilus group $A 3$ (Johnsonet al, 1980) with the type strain of Latohatilus amylatorus (Nakamura 1981). Int J Syst Batcriol 42, 487-491.

Greene, J. D. \& Klaenhammer, T. R. (1994). Factors involved in adherence of hactobacilli to human Caco 2 cclls. Appl Limiron Micrabiol 60,4487 . 4494.

Isolauri, E., Joensuu, J., Suomalainen, H., Luomala, M. \& Vesikari, T. (1995). Improved immunogenicity of oral D $\times$ RR V reassortant rotavirus vaccine by Lattobathis ase GG. I awine 13, 310-312.

Johnson, J. L., Phelps, C. F., Cummins, C. S., London, J. \& Gasser, F. (1980). Taxonomy of the Latobacilis actophilas group. Int I Syit Bacteriol 30, 5.368 .

Johnson, M. C., Ray, B. \& Bhowmik, T. (1987). Selection of Lactobacillus acidophilus strains for use in 'acidophilus products'. Anthonie Leetwenhoek. 53, 215-231.

Kitazawa, H., Matsumura, K., Itoh, T. \& Yamaguchi, T. (1992). 
Interferon induction in murine peritoneai macrophage by stimulation with Lactobacillus acidophilus. Microbiol Immunol 36, 311-315.

Klaenhammer, T. R. (1993). Genctics of bacteriocins produced by lactic acid bactcria. FEMS Microbiol Rev 12,39-85.

Lidbeck, A. \& Nord, C. E. (1993). Lactobacilli and the normal human anaerobic microflora. Clin Infect Dis 16, S181-\$187.

Link-Amster, H., Rochat, F., Saudan, K. Y., Mignot, O. \& Aeschlimann, J. M. (1994). Modulation of a specific humoral immune response and changes in intestinal fora mediated through fermented milk intake. FEMS Immunol Med Microbiol 10, 55-64.

Lortal, S. (1993). Crystalline surface-layers of the genus Lactobacillus. In Advances in Paracrystalline Bacterial Surface Layers, pp. 57-65. Fidited by T. J. Beveridge \& S. F. Koval. New York: Plenum Press.

McGroarty, J. A. (1993). Probiotic use of lactobacilli in the human female urogenital tract. FEMS Immunol Med Microbiol 6, 251 264.

McKay, L. L. \& Baldwin, K. A. (1990). Applications for biotechnology: present and future improvements in lactic acid bacteria. FEMS Microbiol Rev 87, 3-14.

Masuda, K. \& Kawata, T. (1983). Distribution and chemical characterization of regular arrays in the cell walls of strains of the genus Lactobacillus. FEMS Microbiol Lett 20, 145-150.

Messner, P. \& Sleytr, U. B. (1992). Crystalline bacterial cell-surface layers. Adv Microb Pbysiol 33, 213-275.

Mukai, T. \& Arihara, K. (1994). Presence of intestinal lectin-binding glycoproteins on the cell surface of Lactobacillus acidophilus. Biosol Biotech Biochem 58, 1851-1854.

Muriana, P. M. \& Klaenhammer, T. R. (1987). Conjugal transfer of plasmid-encoded determinants for bacteriocin production and immunity in Lactobacillus acidophilus 88. Appl Environ Microbiol 53, $553-560$.

Orrhage, K., Sillerström, E., Gustafsson, J.-Å., Nord, C. E. \& Rafter, J. (1994). Binding of mutagenic heterocyclic amines by intestinal and lactic acid bacteria. Mutat Res 311, 239-248.

Perdigón, G., Medici, M., BibasBonetDeJorrat, M. E., ValverdeDeBudeguer, M. \& PesceDeRuizHolgado, A. (1993). Immunomodulating effects of lactic acid bacteria on mucosal and humoral immunity. Int J Immunotber 9, 29-52.
Pot, B., Hertel, C., Ludwig, W., Descheemaeker, P., Kersters, K. \& Schleifer, K.-H. (1993). Identification and classification of Lactobacillits acidophilus, L. gasseri and L. jobnsonii strains by SDS-P $A \mathrm{GE}$ and rRNA-targeted oligonucleotide probe hybridization. $J$ Gen Microbiol 139, 513-517.

Pot, B., Vandamme, P. \& Kersters, K. (1994). Analysis of electrophoretic whole-organism protein fingerprints. In Chemical Methods in Prokaryotic Systematic, pp, 493-521 Edited by $\mathrm{M}$. Goodfellow \& A. G. O'Donnell. Chichester, UK: Wiley.

Sambrook, J., Fritsch, E. F. \& Maniatis, T. (1989). Molecular Cloning: a Laboratory Mantal, 2nd edn. Cold Spring Harbor, NY: Coild Spring Harbor Laboratory.

Sára, M. \& Sleytr, U. B. (1994). Comparative studies of S-layer proteins from Bacillus stearothermophilus strains expressed during growth in continuous culture under oxygen-limitcd and nonoxygen-limited conditions. I Bacteriol 176, 7182-7189.

Schneitz, C., Nuotio, L. \& Lounatma, K. (1993). Adhesion of Lactobacillus acidopbilus to avian intestinal epithelial cells mediated by the crystalline bacterial cell surface layer (S-layer). I Appl Bacteriol 74, 290-294.

Southern, E. M. (1975). Detection of specific sequences among DNA fragments separated by gel electrophoresis. I Mol Biol 98, 503-517.

Toba, T., Virkola, R., Westerlund, B., Bjorkman, Y., Sillanpăa, J., Vartio, T., Kalkkinen, N. \& Korhonen, T. K. (1995). A collagenbinding S-layer protein in Lactobacillus crispatus. Appl Environ Microbiol 61, 2467-2471.

Tummuru, M. K. R. \& Blaser, M. J. (1993). Rearrangements of sap A homologs with conserved and variable regions in Campylobacter fetus. Proc Natl Acad Sci USA 90, 7265-7269.

Vauterin, L. \& Vauterin, P. (1992). Computer-aided objective comparison of electrophoresis patterns for grouping and identification of microorganisms. Eur Microbiol 1, 37-41.

Zheng, H.-Y., Alcorn, T. M. \& Cohen, M. S. (1994). Effects of $\mathrm{H}_{2} \mathrm{O}_{2}$ producing lactobacilli on Neisseria gonorrboeae growth and catalase activity. I Infect Dis 170, 1209-1215.

Received 1 April 1996; revised 15 May 1996; accepted 17 May 1996. 